\title{
ASSASSINATION OF GANDHI: A HISTORICAL OVERVIEW
}

\author{
Dr. Benish Khan \\ Lecturer Pak-studies \\ Govt Associate College for Women \\ Arifwala, Pakistan \\ benishkhang@gmail.com \\ Dr. Nuzhat Akram \\ Education Officer \\ Pakistan Marine Academy \\ Karachi-Pakistan \\ dr.nuzhatakram@gmail.com \\ Dr. Zahid Mehmood \\ PhD, Post. Doc \\ Maastricht University \\ Netherlands \\ drzahidmehmud@gmail.com
}

\begin{abstract}
This article investigates into the murder of Mohandas Karamchand Gandhi, popularly known as Bapu. Godse the assassin stated that he killed Gandhi as he divided India and also defended the Muslims. His presence was weakening the concept of Akand Baharat. The study delves the motives of fanatic Hindus and protagonist of Hindutva behind the murder of Gandhi. Nehru became the visionary leader of India. The Muslims were further kept aloof. Schism was manifest between the nationalist Indians and fanatic Hindus. The element of Hinduism prevails the Indian politics today in which Muslims have been marginalized.
\end{abstract}

Keywords: Muslims, Indians, Assassination, Protagonist, Hindutva

\section{Introduction}

On $30^{\text {th }}$ of January 1948, at 8 p.m. in New Delhi, a voice spoke on All India Radio. It was a crumbling voice of the then Prime Minister of India, Mr. Jawaharlal Nehru, stating: 


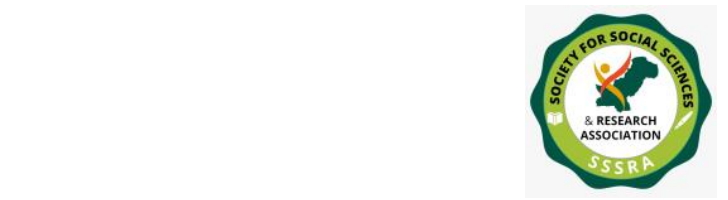

Pak. Journal of Int'L Affairs, Vol 4, Issue 3 (2021)

Assassination of Gandhi: A Historical ...

The light has gone out of our lives and there is darkness everywhere. Our beloved leader, Bapu as we called him, the father of the nation, is no more. The light has gone out, I said and yet I was wrong. For the light that shone in this country was no ordinary light. A light that will still be seen and the world will see it, and it gives solace to innumerable hearts. For that light represented something more than the immediate present; it represented the living, the eternal truths, reminding us of the right path, drawing us of the right path, drawing us from error, taking this ancient country to freedom. (Collins \& Lapierre 1997). With the death of Bapu (Mohandas Karamchand Gandhi), a series of question aroused, and an effort was made to answer those questions. Who killed Gandhi and why he was killed? Was it possible to save the life of Gandhi? What was the impact of death of Gandhi on the politics of India? The assassin, Nathuram Godse (Gupte, 2012), was arrested by the Police and put into custody to inquire about the matter. Investigation was started and many others (Chadha, 1997). were arrested. Interestingly those who were arrested were eye witnesses to the atrocities (Pandey 2001) that were carried out by antihumanitarians during the communal riots that happened after the partition followed by the migration.

The assassin, Godse was hanged on 15 November 1949 (Khatri, 2012). but still there remained a controversy about the cause behind assassinating Gandhi, and who was behind that. The statement given by Godse in the court proved that he alone was responsible for the murder of Gandhi, and the rest who were caught by the police were innocent (FPJ Web Desk. 2019, May 29). The statement of Godse was not true, because he was helped by few others. In order to save others, Godse took the responsibility on him (Ghosh, 1975).

The argument given by Godse for killing Gandhi was based on the acts performed by Gandhi as an Indian leader. Gandhi was not only responsible for dividing India, but he was also responsible for blackmailing the Indian leaders, and defending the Muslims (Johnson 2005). To save India, Godse opined that Gandhi must die, and he must be killed. Godse was of the view that to save Indian nation, the role of Gandhi must be minimized (Jenkins, 1977). He was a threat, he was weakening the concept of Akand Baharat, and he was polluting the Hindu religion (Imhasly, 2007). He used to recite Quran in Muslims' mosque, what does it mean? (Chakravarti, 2010). It means, polluting Hindu religion. Godse also admit that once he was a follower and admirer of Gandhi due to his works in South Africa, but then Gandhi changed, and betrayed the nation by his philosophy (Adams, 2010).

As far as religion was concerned, Godse admitted that he was a Brahman, and had better understanding of Hinduism (Yadav, 2019, May 15). Here Godse uttered his will 


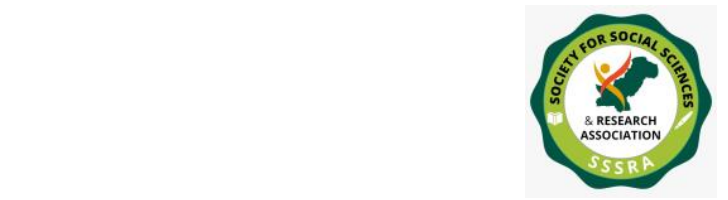

that demarcated between his mentality and the position of Gandhi. He says, "When I die, do not flow my ashes in Ganga rather pass it from generation to generation, and flow them when Akand Baharat is created. (Kuruvachira, 2006)." Why Godse killed Gandhi became clear by his statement, he (Godse) wanted Akand Baharat, whereas Gandhi accepted the partition plan, and negotiated with Muslim leadership.

Inquiry conducted by the government came to the conclusion that Godse was a fanatic and mentally ill (Ghose, 1991). Nothing more than that, here it is interesting that if Godse was mentally ill, then he could have asked for psychiatrist examination, but he never asked for it, rather he denied the appeal that was asked for him by Nehru and the sons of Gandhi (Kulkarni, 2017, May 29). He never tried to run after shooting Gandhi, rather surrendered willingly, and said he know he will be hanged, but he wanted to tell the people why he did it, till the last he had justified his act of killing Gandhi (Krishna, 2007).

Rest of the criminals accepted the charge that they were involved in hatching the plan with Godse. Why they joined Godse, they have a similar cause, and that was because Gandhi ignored the suffering of his people and was favoring Muslims who were butchering the Hindus. Gandhi ignored Hindus, their mothers, daughters, children and sided with the Muslims. In short, Gandhi had tied the hands of the Hindus and had allowed the Muslims to do what they could. From the words of members of RSS (Rashtriya Swayamsevak Sangh), it was predictable that for them Hindu nationalism was more sacred to them as compared to Gandhism. So, to help Hindus, they agreed with the plan of Godse, and helped him.

The statement of Hindu nationalists, who were involved in hatching the conspiracy for assassinating Gandhi, linked Savarkar with the case (murder of Gandhi). It was Savarkar who propounded the idea of Hindutva (Narayan, 2009). It was Savarkar who provided arms to the Hindus to massacre the Muslims during communal riots (McKean, 1996). It was Savarkar who became the founder of Hindu Mahasabha, and its militant wing, known as RSS (Nussbaum, 2008). Savarkar was linked behind every serious communal crime because of his past carrier (Noorani, 2012, October 5). Godse and Apte were workers of newspaper owned by Savarkar, and they frequently visited him (Douglass, 2012). Savarkar became a prime suspect, but was released because of lack of evidences.

\section{Hatching of the plan}




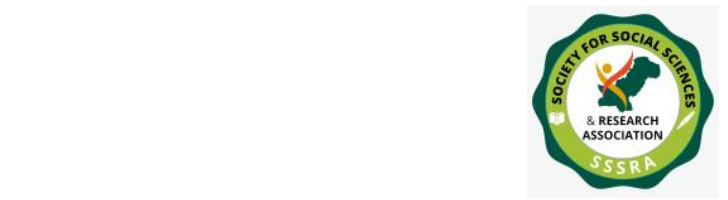

Godse was the main plotter behind the assassination of Gandhi. He was the one who contacted other and used RSS platform to make his plan practical. Savarkar was blamed for corrupting the youth through his idea of Hindutva. When Godse was dropped out of high school, he became a member of RSS and contacted those who were active in killing of Muslims during communal riots (Chakravarti, 2010). Digambar Badge an arm supplier was asked by Godse to arrange two revolvers, two guncotton slabs and five hand grenades to be delivered to Hindu Mahasabha office in Bombay on 14 January (Malgonkar, 1979). To assassinate Gandhi on 12 January when he was going to fast for the payment of 550m rupees to Pakistan (Gauba, 1969).

Narayan Apte who was a school teacher at Poona who owned a Marathi newspaper named as Agrani. With the advice of Godse, he renamed his newspaper as Hindu Rashtra. During his twenties, Apte was a member of Rashtra Dal, a society of Hindu Militant Youths, where he used to organize militants with the help of Nathuram (Chadha, 1997).

Gopal Godse brother of Nathuram Godse was also inspired by Savarkar's philosophy and his (Savarkar's) war against the idea of vivisection of India. Nathuram warned him to think twice before joining him as he was married and had two daughters.

Madanlal Pahwa, who escaped from Pakpattan, witnessed the massacre of Hindus by the Muslims after partition. He lived in a refugee camp near Poona, where he heard congress part speaking against Hindu Muslim unity. It was December 1947 when he came into contact with Godse and Apte (Chadha, 1997). They were finding a dependable member.

Vishnu Karkare the hotel owner at Ahmednagar became a member of Hindu Mahasabha after witnessing the kidnapping of Hindu women by Muslims (Corbridge, Harriss, \& Jeffrey, 2013). He came under the influence of Nathuram, because of his fearless publishing of atrocities in Noakhali (Corbridge, Harriss, \& Jeffrey, 2013). He was so much inspired by Nathuram that he started supporting his (Nathuram's) idea of killing Gandhi, who for them has became a threat for the Hindus.

Dattatraya Parchure became a member of Hindu Mahasabha and was elected as the leader of Hindu militant, thus he came into contact with the Hindu Mahasabha, but he was never a trusted ally. Another man, Shankar Kistayya was the agent of Badge; he was to provide arms to the customers of Badge. But he was also involved by Nathuram in his plan of killing Gandhi. 


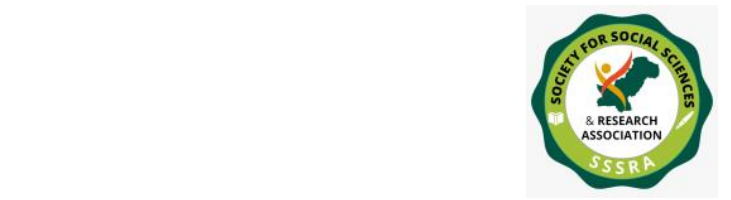

Plan was discussed at Poona, Bombay and Delhi. Kastayya was to shoot Gandhi, and he was unaware why he has to kill Gandhi. Godse wrote his will and made Apte and Gopal's wife the beneficiaries of his insurance policies, i.e. Rs. 5000 (Chadha, 1999). When Godse and Apte took train to Bombay, there Apte met Bimba-a film actress, real name Shanta Modak (Malgonkar, 2008). At the stop of the railway station, she asked to drop them as they were to go to Savarkar's sadan-half a mile from Modak destination, i.e. Shivaji park. This made the women witness against Savarkar in court, but she didn't see them entering the house (Malgonkar, 2008).

On the other hand, Gopal requested for seven days leave with effect from 15 January, on the ground that he had some important wok in his village, but the leave was granted to him on 17 January (Chadha, 1999). In Bombay, by chance Pahwa met Dr. Jagdish Chandra, the man who gave a job to Pahwa (Jain, 1987). During conversation with him, Pahwa told Chandra that he has joined a group of conspirators and has planned to kill Gandhi. Chandra did not take the words of Pahwa seriously because most of the refugee used to utter such words, however Chandra warned Pahwa of dire consequences, and advised him to keep aloof.

On 14 January, plan for going to Delhi was explained and instructions were given who was going to do what. In Bombay the bag containing the arsenals were kept at Dixit Maharaj's house who was a nationalist and religious leader. His house served as an anti Muslim symbol (Chadha, 1999). Godse, Apte, Badge, Pahwa, and Karkare visited Dixit and asked him to tell them the technique of throwing hand grenade, but he was never informed of the plan. Revenue and arms were collected and stored in Bombay (Chadha, 1999).

On $17^{\text {th }}$ January, Badge and Kistayya left for Delhi via train and Godse and Apte by plane. In Delhi they (Godse and Apte) stayed at marina hotel till $20^{\text {th }}$ January (Douglass, 2012). Badge and Kistayya stayed in Hindu Mahasabha's office. Gopal got late and reached on 19. Apte and Godse visited Birla house on the evening (5 pm) of 17 (Ghosh, 1975). On $19^{\text {th }}$ of January members of Hindu Mahasabha were shocked to see that Muslims are moving freely and greeted by Sikhs and Hindus (Chadha, 1999). For them, Gandhi had succeeded. In the same day, in morning, a long call was booked from Hindu Mahasabha office and the number was of Savarkar's house, but the name for talk was given as Damle (secretary of Savarkar) and Appa Kesar (bodyguard of Savarkar). No one accepted that he had booked the call to save himself (Chadha, 1999).

\section{First attempt $20^{\text {th }}$ January 1948}




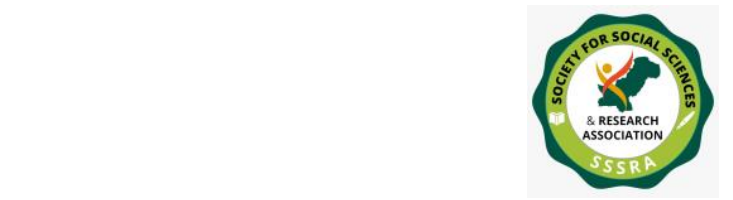

Plan for first attempt was made in marina hotel in the morning of $20^{\text {th }}$ January. The first plan was as followed: Pahwa would be having a hand grenade and a gun cotton slab, Badge and his servant Kistayya would be having a hand grenade and a revolver, Gopal and Karkare would be having a hand grenade each, Nathuram and Apte would be giving signals. Pahwa would explode the gun cotton slabs and Badge would shoot Gandhi from behind the trees, then Pahwa would throw his hand grenade. Kistayya would also do the same, then Apte and Nathuram would give the signal and they would mix in the crowd and leave (Chadha, 1999).

At 4.30 they left for Birla house, but at the gate badge saw a one eye man sitting at the entrance which means bad luck and a death trap for badge, so he asked his fellows to allow him to shot Gandhi from the front, and Nathuram and Apte accepted his plea (Collins, \& Dominique 1997). Now Pahwa had to explode the gun cotton and Badge would shoot Gandhi and the rest followed as it was planned, but all their arsenals were in a taxi that was standing outside the Birla house.

Badge went to the taxi with Kistayya took the revolvers and threw them at the back of the taxi, and gave the hand grenade to Kistayya, and then he went to Birla house and assured Apte and Nathuram that he was ready (Chadha, 1999). The others also took with them their hand grenades. When Pahwa ignited the guncotton slab, the blast shook the ground, but nothing happened. Gandhi asked the audience to remain calm. Gandhi said, "Listen! Listen! It is nothing. It is just the army having some practice," and the prayer continued (Collins, \& Dominique 1997). Pahwa who had never visited Birla house before tried to escape, but a woman saw him and screamed that he was the man, and so Pahwa was arrested (Collins \& Dominique 1997).

Gopal went to the taxi and saw the revolvers there, he took one and moved towards the servant quarter from where he thought to kill Gandhi, but he failed as the height was more than he expected, (Chadha, 1999). thus he rushed outside where he found Apte, Nathuram and Karkare waiting for him. The first attempt failed.

\section{Plan for Assassination and Death of Gandhi}

The same evening i.e. $20^{\text {th }}$ January, Apte and Nathuram went to Hindu Mahasabha office and on their way they encountered Badge and asked him why he betrayed them, so Badge was annoyed and he left them. Actually badge never wanted to kill Gandhi; he wanted to get his weapons sold, which he also confessed in the court (Chadha, 1999). Karkare and Gopal went to old Delhi, badge and Kistayya went to Poona the following night, Nathuram and Apte went to Cawnpore. On 23 January Apte and Nathuram took train for 


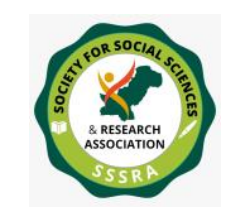

Pak. Journal of Int'L Affairs, Vol 4, Issue 3 (2021)

Assassination of Gandhi: A Historical ...

Bombay. In their compartment which was of first class, Nathuram told Apte that now he was going to do it all alone, and he wanted to see Gandhi dead before his eyes (Cookman, 1998).

On the other hand, police searched the room of Pahwa and found Hindu Mahasabha papers on which the murder plot was written, and the author was none but Nathuram. Numbers of guards were increased at Birla house following the orders of home minister Vallabhai Patel, but none of the responsible department took action against the conspirators. On the other hand deputy commissioner of police (Bombay intelligence branch) J.D. Nagarvala "(jimmy)" did not cooperate with the Delhi police officers who were sent to collect witnesses as they were juniors in rank to Nagarvala (Collins, \& Lapierre, 1997).

This time, Nathuram decided to carry out his plane single handedly, so he did not allow his brother to join him, but Apte and Karkare remained with Nathuram. On $26^{\text {th }}$ January, they went to Bombay, and took loan of Rs. 10000 for his newspaper from Savarkar (Chadha, 1999). In fact Nathuram needed the money to buy a good weapon. On $27^{\text {th }}$ January, Apte and Nathuram went to old Delhi to the house of Dattatrata Parchure, a member of Hindu Mahasabha, and personally close to Nathuram (Chadha, 1999). Nathuram asked from him for a revolver, which he was fetched at a price of Rs. 500 . (Mahatma Gandhi Foundation, n.d). On the morning of $29^{\text {th }}$ January, Nathuram and Apte reached Delhi, joined by Karkare. Apte and Karkare were confused about the planning but Nathuram was relaxed and had already told Karkare that he was going to do it alone. Apte had a family and must run the newspaper, and you (Karkare) help him in running the paper. Moreover, he said that he will also be able to justify why he killed Gandhi. "I am an orator and a writer, and I shall be able to justify my act and impress the government and the court of my good faith in killing Gandhi." (Chadha, 1999).

On the morning of $30^{\text {th }}$ January, Nathuram was relaxed as if he has nothing to do, whereas Apte and Karkare were confused, and they visited Birla house. When they came back they told Nathuram that there were a lot of policemen at the gate but luckily no one was from their area to recognize them, and all were from northern part of the country (Chadha, 1999). At 4.30 pm, Nathuram went to Birla house, and joined the crowd of 500 people (Chadha, 1999). Suddenly there was restlessness in the crowd and everyone stood up, Gandhi was coming resting support upon the shoulders of his two nieces (Abha and Manu). Nathuram came forward and bowed before Gandhi, and suddenly pushed one of the nieces (Manubehn) and fired three shots in the chest of Gandhi. Gandhi fell down, according to Nathuram saying Ahh (Cry due to pain), and not Hey Ram (Oh God) (Lal, 2017). The time was $5.15 \mathrm{pm}$. Nathuram was arrested by the police and investigation 


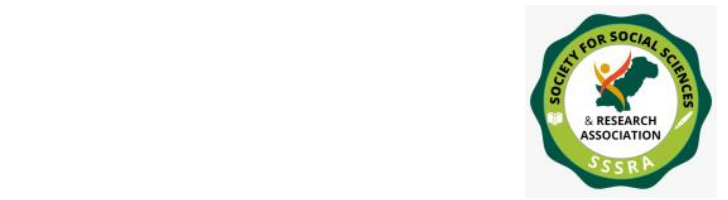

Pak. Journal of Int'L Affairs, Vol 4, Issue 3 (2021)

Assassination of Gandhi: A Historical ...

began at a country level and all were arrested and interrogated. Death of Gandhi was confirmed by Nehru.

\section{New Inquiry and Findings of Kapur Commission Report 1969}

Soon after the death of Gandhi, RSS was banned and a gap emerged between Hindu nationalism and Indian nationalism. Hatred emerged for the members of Hindu Mahasabha. RSS disowned Godse for his act of killing Gandhi. Interestingly when Gopal and rest were released, sweets were distributed in the office of Hindu Mahasabha, and it aroused the people (Noorani, 2002). A suspicion aroused whether Hindu Mahasabha was involved in the killing of Gandhi? The case was reopened in 1966 under Justice Jeevaan Lal Kapur, and its report (Kapur commission report) shocked the previous judgments.

The findings of Kapur Commission was having an edge that it got the witnesses of the secretary Damle and bodyguard Kasar of Savarkar, who in 1948 did not say what they disclosed to Kapur Commission (Douglass, 2012). Kapur Commission gave its remarks as, "All these facts taken together were destructive of any theory other than the conspiracy to murder by Savarkar and his group." (Kapur \& Kapur 1970) But during 1948 the home minister who did not permit the DCP to arrest Savarkar (Chadha, 1999).

The validity of Kapur Commission was also questioned because the Commission was headed by only one judge i.e. Kapur. It was said that there must have been at least three judges. And as far as the case for Savarkar was concerned, he was dead till that time; so that he could defend his position before the Commission. During that time, when bomb was blasted by Pahwa on January $20^{\text {th }} 1948$, the police kept Savarkar under house arrest and kept a watch on all his activities, (Noorani, 2012, October 5), if there was any suspicion then Savarkar would have been arrested and evidences were produced in the court. Another thing worthy of notice is that, Savarkar remained under house arrest after January 20, 1948 till assassination of Gandhi (Savarkar, \& Raje, 1989).

The question was raised that it was a political rivalry against RSS due to which Savarkar was time and again blamed for killing Gandhi (Bandyopadhyay, 2009). The government was well aware of the plan for killing of Gandhi, then why it did not stop it. There were multiple reasons for that: 1). Gandhi himself did not allow security for his life, rather he disliked it. He said if such an act was done, he would leave Delhi (Parekh, 2010). To make Gandhi understand was near to impossible because he believed that his life is under the will of God, and he needs no protection (Murthi, 1998). and did not like the police to search those who were coming to his prayer. He even asked the police to leave Pahwa (Collins \& Lapierre 1997). 2). The government did not take it serious 


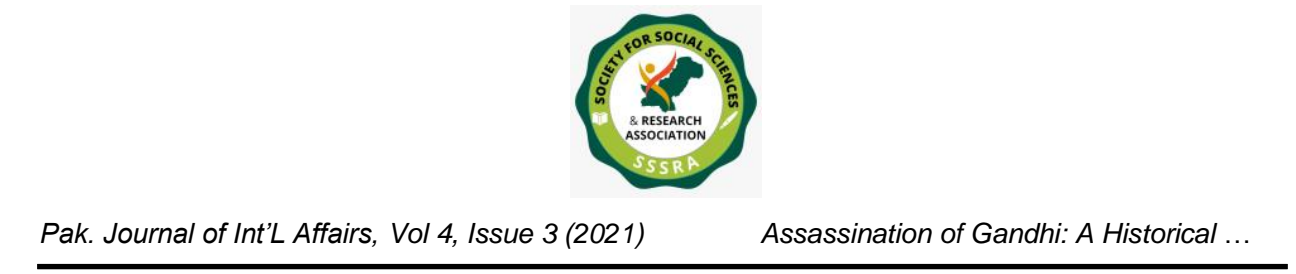

because before the partition , several attempts were made on Gandhi to kill him (Kapur, \& Kapur, 1970), so the government thought not to give ear to rumors, and why one should kill Gandhi who is bapu (father) of the nation. 3). There was lack of cooperation between the police department in Delhi and in Bombay. After the bomb blast at Birla house, when Delhi police tried to get other suspects from Bombay on the statements of Manila, Delhi police did not cooperate. 4). Fear of government also played another role, after bomb blast when Savarkar was suspected, government failed to arrest Savarkar for investigation on the reason that if Savarkar was arrested then may be a mob will rise (Noorani, 2012, October 5)., and it will be difficult to control them, especially at a time, when communal issue is not settled yet. So there were multiple factors responsible that led to the assassination of Gandhi.

When Gandhi was shot dead by Godse, and Mountbatten came to visit the dead leader of India, a person among the crowd shouted that the one who had killed Gandhi was a Muslim. Mountbatten at once turned towards him and said, "You fool", "don't you know it was a Hindu?" (Collins, \& Lapierre, 1997). Campbell Johnson asked Mountbatten how he knew he was a Hindu. Mountbatten argued that he does not know but the killer must be a Hindu, otherwise we will loose India (Collins, \& Lapierre, 1997). Here we see how much communal hatred was deep rooted among the Indians. It can also be judged that at the movement an attempt was made to exploit communalism and defeat Gandhi's effort of restoring peace in terms of communalism, because a day before his killing, violence on the basis of communalism ended in Delhi.

Outcomes that became apparent after the assassination of Gandhi needs elaboration because the future of Indian politics was dependent on that outcome. The differences between Nehru and Patel ended. Prior to that Patel had given his resignation before Gandhi but Mountbatten asked Gandhi not to accept it, because India need both of them (Gopal, 2015), and it was Mountbatten who after the death of Gandhi disclosed the fact that Gandhi wanted an end to the differences existing between Nehru and Patel, and they must do it, at least now when Gandhi was dead (Collins, \& Lapierre, 1997).

\section{Assassination of Gandhi and Politics in India}

Death of Gandhi made Nehru the unsung hero and supreme authority in Indian politics (Crocker, 2011). It seemed as if Nehru was the heir of Gandhi in politics. Nehru was seen as if accomplishing the task that was left undone by Gandhi. Death of Gandhi gave Nehru a chance to implement his policy of shining India (Crocker, 2011), i.e to make India a secular state, by using the legitimacy of bapu. Criticism on the policies of Nehru was avoided on the ground that he was manifesting the best which he learnt from Mahatma 


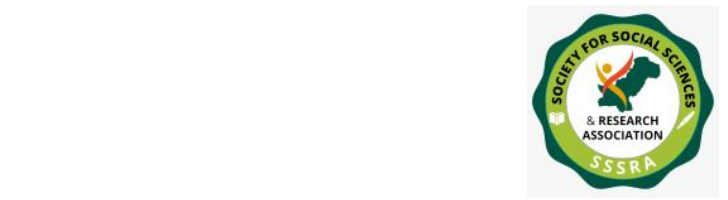

(the great soul). The India that survived after the death of Gandhi was not the India of bapu rather it was the Nehruian state molded by his vision and ideas (Larson, 1995). It was Nehru who gave India what it needed for its strength and success. The congress party also became a working party due to its legitimacy that it owned from Gandhi and Nehru. However after partition, Gandhi was rarely asked for any advice, rather he lost his say in Indian politics (Collins, \& Lapierre, 1997). Gandhi told Mountbatten, "They (Nehru, Patel and Congress) listen to you now more than they do to me." (Collins, \& Lapierre, 1997).

The assassination of Gandhi by Nathuram created hatred against Hindu Mahasabha (Hibbard, 2010), thus dividing Indian nationalism from Hindu nationalism. However during the life of Gandhi every possible attempt was made to bring both the nationalism on the same line. Such nationalism means a threat for the minorities, and it was clear after post partition when the government did not raided or banned Hindu nationalist who were involved in communal killings, and supply of every type of arsenals (Naqvi, n.d.). After the assassination, Hindu Mahasabha was banned and as well as its militant wing i.e. RSS. (Gopal, 1994) Hindu Mahasabha was seen as a party anti to India and responsible for the killing of Mahatma. The party prior to its ban disowned and dismissed the membership of Nathuram (Puniyani, 2001). However within a year the ban was lift because of public pressure and keeping in view the declaration of government stating that Nathuram was a fanatic. Thus ended the influence of Hindu Mahasabha in the politics of India, and it became a mass political party but depending on the instruction of govt. still this division continues in India, Hindu nationalism vs. Indian nationalism.

Death of Gandhi manifested what he has prophesized, and was trying to stop (Lapierre, Collins, \& Mordekar, 2017). Communal disharmony led to wars and enmity between the two communities, who have once lived together for centuries. Prior to the assassination of Gandhi he wished to visit Pakistan and asked Jinnah to work for the communal harmony in his country (Lapierre, Collins, \& Mordekar, 2017). Interestingly Jinnah had planned for communal harmony much before the partition. He (Jinnah) was the one who was always concerned for the rights and safety of the minorities. Gandhi promised to visit Pakistan when he would be successful in bringing peace in India. Thus ended the vision of both the leaders, and soon Pakistan was seen as having wars with India years after years, because the Hindu nationalist never accepted Pakistan as a reality.

\section{Conclusion}

The death of Mahatma gave a chance to other existing ideologies to show their colors to the world especially to the newly created Pakistan. Death of Gandhi was shown as a great 
sacrifice for the Muslim and especially for the Muslims of Pakistan. In short, the Muslims were shown as villain committing heinous crime in Pakistan with the Hindu community but Gandhi was fasting for their safety in India against Hindus. Gandhi was portrayed as a hero for the Indians irrespective of any communal community, and thus Gandhi being a symbol of congress representing all the communities in India. When Gandhi was alive, he was reported to have said to Mountbatten that "now no one is willing to listen me until I declare fast unto death." The Mahatma that was left in a merciless condition and was seen as saying that he does not want to die as a failure. Looking into the pages of history it is obvious that great leaders die while their nation lives and they are used by their successors as a symbol for their rule, the same happened with Gandhi and his ideology. 


\section{References}

Adams, J. (2010). Gandhi: Naked Ambition. Quercus Publication.

Bandyopadhyay, S. (2009). Decolonization in South Asia: Meanings of freedom in postindependence West Bengal, 1947-52. Routledge.

Chadha, Y. (1997). Gandhi: A Life. Wiley.

Chadha, Y. (1999). Gandhi. Wiley.

Chadha,Y. (1997). Rediscovering Gandhi. Century Books.

Chakravarti, D. (2010). The Politics Around the Assassination of MK Gandhi. Available at SSRN 1687663.

Collins, L. \& Lapierre, D. (1997). Freedom at Midnight: The Epic Drama of India's Struggle for Independence. Harper Collins Publishers.

Cookman, C. (1998). Margaret Bourke-White and Henri Cartier-Bresson: Gandhi's funeral. History of Photography, 22(2), 199-209.

Corbridge, S., Harriss, J., \& Jeffrey, C. (2013). India today: Economy, politics and society. John Wiley \& Sons.

Crocker, W. (2011). Nehru: A Contemporary's Estimate. Random House India.

Douglass, J. W.(2012). Gandhi and the Unspeakable: His Final Experiment with Truth.Orbis Books

FPJ Web Desk. (2019, May 29). Why I killed Gandhi: Godes final words. The Free Press Journal. https://www.freepressjournal.in/india/why-i-killed-gandhi-godses-finaladdress.

Gauba, K. L. (1969). The Assassination of Mahatma Gandhi. Jaico Publishing House.

Ghose, S. (1991). Mahatma Gandhi. Allied Publishers.

Ghosh, T. (1975). The Gandhi Murder Tria. Asia Publications House. 
Gopal, R. (1994). Hindu culture during and after Muslim rule: survival and subsequent challenges. MD Publications Pvt. Ltd..

Gopal, S. (2015). Jawaharlal Nehru; a Biography Volume 1 1889-1947. Random House.

Gupte, P. (2012). Mother India: a political biography of Indira Gandhi. Penguin Books India.

Hibbard, S. W. (2010). Religious politics and secular states: Egypt, India, and the United States. JHU Press.

Imhasly, B. (2007). Goodbye to Gandhi?: Travels in the New India. Penguin Books India.

Jain, J. C. (1987). Gandhi: The Forgotten Mahatma. Mittal Publication.

Jenkins, A. (1977). The Forties. Universe Books.

Johnson, R. L. (Ed.). (2005). Gandhi's experiments with truth: Essential writings by and about Mahatma Gandhi. Lexington Books.

Kapur, J. L., \& Kapur, J. L. (1970). Report of Commission of Inquiry Into Conspiracy to Murder Mahatma Gandhi. Ministry of Home affairs.

Khatri,V. (2012).World Famous Trial. Pustak Mahal.

Krishna, K. (2007). Battle For Peace. Penguin Books.

Kulkarni, P. (2017, May 29). How Savarkar Escaped Conviction For Gandhi's Assassination. The Wire. https://thewire.in/history/savarkar-gandhi-assassination.

Kuruvachira, J. (2006). Hindu Nationalists of Modern India: A Critical Study of the Intellectual Genealogy of Hindutva.Rawat Publications.

Lal, V. (2017). India and its Neighbours. UCLA Social Science. https://southasia.ucla.edu/.

Lapierre, D., Collins, L., \& Mordekar, M. (2017). Freedom at midnight. Mehta Publishing House. 
Larson, G. J. (1995). India's agony over religion. Suny Press.

Mahatma Gandhi Foundation. (n.d). The Official Mahatma Gandhi eArchive \& Reference Library, http://www.mahatma.org.in/mahatma/conspirators/conspdesc.jsp?link=ld\&id=9\& cat $=$ conspirators, $\% 20$ accessed\%20on\%2026-11-2013.

Malgonkar, M. (1979). The Men Who Killed Gandhi. Macmillan Publishers Limited.

Malgonkar, M. (2008). The Men Who Killed Gandhi. Roli Books.

McKean, L. (1996). Divine Enterprise: Gurus and the Hindu nationalist movement. University of Chicago Press.

Murthi, R. K. (1998). Tales from Mahatma Gandhi's Life. Pitambar Publishing.

Naqvi, S. (n.d.) Congress may not have Been always Averse To RSS. The Sunday Guardian. http://www.sunday-guardian.com/analysis/congress-may-not-havebeen-always-averse-to-rss

Narayan, B. (2009). Fascinating Hindutva: Saffron Politics and Dalit Mobilisation. Sage Publications.

Noorani, A. G. (2012, October 5). Savarkar and Gandhis murder. Frontline: India's National Magazine. https://frontline.thehindu.com/thenation/article30167715.ece.

Noorani, A. G. A. M. (2002). Savarkar and Hindutva: The Godse Connection. LeftWord Books.

Nussbaum, M. (2008). The Clash Within: Democracy, Religious Violence, and India's Future. Havard University Press.

Pandey, G. (2001). Remembering Partition: Violence, Nationalism and History in India. Cambridge University Press.

Parekh, B. C. (2010). Gandhi. Sterling Publishing Company, Inc.. 
Puniyani, R. (2001). Communal Politics: an illustrated primer. Safdar Hashmi Memorial Trust.

Savarkar, V. D., \& Raje, S. (1989). Savarkar Commemoration Volume. Savarkar Darshan Pratishthan.

Yadav, Y. (2019, May 15). Godse, raised as a girl, saw Gandhi as an 'effeminate' Father who didn't protect Mother India. The Print. https://theprint.in/opinion/godseraised-as-a-girl-saw-gandhi-as-an-effeminate-father-who-didnt-protect-motherindia/235838/. 